\title{
Contract Law and Economics
}

Edited by

\section{Gerrit De Geest}

Professor of Law, Washington University in St Louis, USA

ENCYCLOPEDIA OF LAW AND ECONOMICS, SECOND EDITION

\section{Edward Elgar}

Cheltenham, UK • Northampton, MA, USA 
(C) The Editor and Contributors Severally 2011

All rights reserved. No part of this publication may be reproduced, stored in a retrieval system or transmitted in any form or by any means, electronic, mechanical or photocopying, recording, or otherwise without the prior permission of the publisher.

Published by

Edward Elgar Publishing Limited

The Lypiatts

15 Lansdown Road

Cheltenham

Glos GL50 2JA

UK

Edward Elgar Publishing, Inc.

William Pratt House

9 Dewey Court

Northampton

Massachusetts 01060

USA

A catalogue record for this book is available from the British Library

Library of Congress Control Number: 2009943918

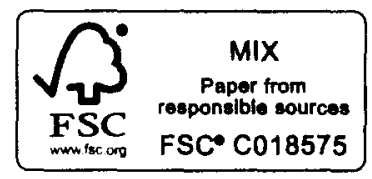

ISBN 9781847206008

Typeset by Servis Filmsetting Ltd, Stockport, Cheshire Printed and bound by MPG Books Group, UK 


\section{Contents}

List of contributors vii

1. Introduction 1

Gerrit De Geest

\section{PART I FORMATION AND INTERPRETATION}

2. Precontractual liability 9

Eleonora C. Melato

3. Contractual mistake and misrepresentation 31 Qi Zhou

4. Duress

Péter Cserne

5. Gratuitous promises $\quad 80$

Robert A. Prentice

6. Gifts, wills and inheritance law 96

Pierre Pestieau

$\begin{array}{ll}\text { 7. Standard form contracts } & 115\end{array}$

Clayton P. Gillette

8. Interpretation and implied terms in contract law 125

George M. Cohen

\section{PART II REMEDIES}

9. Contract remedies: general 155

Paul G. Mahoney

10. Penalty clauses and liquidated damages 178

Steven Walt

11. Impossibility and impracticability 207

Donald J. Simythe

12. Foreseeability 225

Peter van Wijck

13. Option contracts and the holdup problem 239

Abraham L. Wickelgren

14. Warranties 256

Klaus Wehrt 
vi Contract law and economics

\section{PART III LONG-TERM CONTRACTS}

15. Long-term contracts and relational contracts 281 Nick van der Beek

16. Long-term contracts in the law and economics literature Mireia Artigot $i$ Golobardes and Fernando Gómez Pomar

17. Marriage contracts Antony $W$. Dnes

18. Franchise contracts

\section{PART IV PERSPECTIVES}

19. Behavioral approaches to contract law Ann-Sophie Vandenberghe

20. The civil law of contract

Ejan Mackaay

21. Unjust enrichment and quasi-contracts

Christopher T. Wonnell

Index 


\section{Contributors}

Mireia Artigot i Golobardes, Professor of Law, Universitat Pompeu Fabra

George M. Cohen, Brokaw Professor of Corporate Law and Barron F. Black Research Professor of Law, University of Virginia School of Law

Péter Cserne, Senior Research Fellow, Tilburg Law and Economics Center (TILEC), Tilburg University

Gerrit De Geest, Professor of Law and Director of the Center on Law, Innovation \& Economic Growth, School of Law Washington University

Antony W. Dnes, Professor of Economics, University of San Diego

Clayton P. Gillette, Max E. Greenberg Professor of Contract Law, New York University School Of Law

Fernando Gómez Pomar, Professor of Law and Economics, Universitat Pompeu Fabra

Ejan Mackaay, Emeritus Professor of Law, University of Montreal

Paul G. Mahoney, Dean and David and Mary Harrison Distinguished Professor of Law and Arnold H. Leon Professor of Law, University of Virginia School of Law

Eleonora C. Melato, School of Law Washington University

Pierre Pestieau, Professor Emeritus, Université de Liège and member of CORE, Université Catholique de Louvain

Robert A. Prentice, Ed and Molly Smith Centennial Professor of Business Law, McCombs School of Business, University of Texas at Austin

Donald J. Smythe, Professor of Law, California Western School of Law

Nick van der Beek, Researcher, Utrecht University, the Netherlands; ZBC MultiCare, outpatient clinic for dermatology, Hilversum, the Netherlands; University of Wales 
viii Contract law and economics

Peter van Wijck, Assistant Professor of Economics, Leiden University and coordinator strategy development, Dutch Ministry of Justice

Ann-Sophie Vandenberghe, Assistant Professor Law and Economics, Erasmus University Rotterdam

Steven Walt, Percy Brown Jr. Professor, University of Virginia School of Law

Klaus Wehrt, Professor of Economics and Statistics, Hochschule Harz

Abraham L. Wickelgren, Bernard J. Ward Centennial Professor, University of Texas School of Law

Christopher T. Wonnell, Professor of Law, University of San Diego School of Law

Qi Zhou, Lecturer in Law, University of Sheffield 
1 Introduction

Gerrit De Geest

This volume provides an overview of the economic literature on contract law. There follow 20 chapters, all written by experts in the field. Each chapter offers a thorough review of the literature, an extensive bibliography, and a personal reflection on avenues of future research. Only seven of the 20 chapters are updated versions of chapters that appeared in the 2000 edition of the Encyclopedia of Law and Economics; the 13 other chapters are completely new. This is in line with the ambitious nature of the second edition of the Encyclopedia: to increase the coverage from five to 12 volumes, and from 4,300 pages to nearly double that size.

Contract law is one of the classic fields of law. It is also one of the first studied by law and economics scholars. It started, in a sense, with Coase (1960), whose seminal article can be interpreted as a call to solve externality problems through contract law. In the late 1960s, Birmingham, Barton, and others started to analyze specific contract law doctrines (see, for example, Birmingham, 1969; Barton, 1972). The first monographs on law and economics (Tullock, 1971; Posner, 1973) each devoted separate chapters to contract law. Since then, the literature has steadily grown. Remarkably, many of these contributions appeared in American law reviews - apparently more than for most other fields.

Economic analysis of contract law got an extra boost in the 1980s, when institutional economics gained popularity and mainstream economists started to study contracts. Economists started to see organizations as solutions to principal-agent problems, and contracts as the archetypical form of organization on markets. The central role that contracts play in economic literature is illustrated by the fact that a recent synthesis of industrial organization literature (by Bolton and Dewatripont, 2005) is entitled Contract Theory. Summarizing this economic literature is not this volume's primary goal, though; our focus is on the literature that yields implications for contract law. Even so, especially in Part III on long-term contracts, the authors will refer to the industrial organization literature.

If we compare contract law with tort law and litigation law, we see that contracts are analytically more complex than torts, but probably less complex than litigation. A tort is analytically a bilateral incentive problem, without much information exchange or strategic interaction. A contract is also a bilateral incentive problem, but with extensive opportunities for 


\section{Contract law and economics}

information exchange and strategic interaction. Litigation is not only a bilateral incentive problem with informational and game-theoretical components, but it also involves externalities to the society as a whole, in the form of subsidies, precedent-creation, and law enforcement. Because of this complexity, the economic literature on contract law is probably not so well developed as similar literature on tort law, but better developed than similar literature on litigation. This differing degree of complexity may also help to explain why there is probably less consensus on optimal contract law than on optimal tort law (though more than on optimal litigation law).

This volume is divided in four parts. Part I deals with contract formation and interpretation; Part II deals with remedies for breach; Part III discusses long-term contracts; and Part IV offers some perspectives.

Part I starts with a review of the literature on precontractual liability - a somewhat under-researched field, probably because it plays only a minor role in American law as compared to civil law systems. Eleonora C. Melato in Chapter 2 shows how the literature has analyzed the law's effect on how the contracting parties exchange information, invest, and behave in a strategic manner.

In Chapter 3, Qi Zhou discusses contractual mistake and misrepresentation. A mistake may lead to inefficiency because goods may not end up in the hands of the highest-value user. Even so, this does not imply that the law should automatically avoid all mistaken contracts, since this would also alter the incentives of parties to search for, disclose, and rely on information. The author argues that a distinction should be made between fraudulent misrepresentation (where the law's goals should be to simply deter the parties from deceiving), negligent misrepresentation (where the law should induce the representor to take socially optimal care), and innocent misrepresentation (where the law should shift attention to the incentives of the representee).

Chapter 4 is devoted to duress. When parties are under pressure to enter into contracts, there is no guarantee that the exchange is Pareto superior. Yet defining illegal threats is difficult, since threats play a role in nearly every negotiation. Similarly, it is hard to distinguish welfare-decreasing duress from welfare-increasing adaptation of the contract to changed circumstances. Until recently, philosophers and economists have struggled to come up with the precise criteria for duress, despite their emphasis on the importance of voluntary exchanges. Duress seems to be a topic where philosophers and economists can learn from law and economics scholars. Péter Cserne illustrates the progress made in explaining doctrines such as duress, necessity, and unconscionability.

The next two chapters deal with gratuitous promises, gifts, wills, and 
inheritance law. Common law contract doctrine traditionally refuses to enforce promises that are not the product of a bargained-for exchange. This stands in contrast to civil law systems, which tend to enforce gratuitous promises, at least if certain formalities are fulfilled. Robert A. Prentice summarizes in Chapter 5, the insights that economists have brought to this discussion, though he concludes that narrowly defined rational choice models may not be able to fully explain the intrinsically social phenomenon of gift-giving. In Chapter 6, Pierre Pestieau surveys recent theoretical and empirical work on bequeathing, and shows that regulation and taxation have an undeniable effect on the level, pattern, and timing of bequests.

Chapter 7 on standard form contracts, written by Clayton P. Gillette, surveys a part of the literature that has grown exponentially in recent years. In earlier times, economists looked favorably at standard term contracts, emphasizing how such contracts saved on transaction costs. Lawyers, in contrast, were more critical, observing the many abuses that occur in practice when parties have no real opportunity to read, understand, or negotiate contract terms. The new economic literature, which uses behavioral models, seems to bridge that gap.

In the final chapter of Part I, Chapter 8, George M. Cohen surveys the literature on interpretation and implied terms - another field that has received increased attention from law and economics scholars in recent years. Cohen concludes that optimal interpretation rules depend on institutional context. A contextualist interpretation, which allows courts to more easily intervene, is superior only when courts can easily assess contextual evidence and police against opportunistic behavior, and when extralegal enforcement is ineffective.

Part II of this volume deals with remedies. In the first chapter, Chapter 9, Paul G. Mahoney gives an overview of the general literature on remedies for contract breach - probably the most researched topic of contract law and economics. His survey illuminates the richness of the current theoretical apparatus, which takes numerous types of incentives and numerous complications (including asymmetric information and strategic behavior) into consideration.

Steven Walt reviews the economic literature on penalty clauses and liquidated damages in Chapter 10. The common law refuses to enforce penalty clauses (which are contractually stipulated damages that exceed reasonable forecasts of damages). Legal economists have always been puzzled by this doctrine. Walt finds that penalty clauses do make economic sense under some conditions. He therefore concludes that a systematic prohibition of penalty clauses cannot be justified.

In Chapter 11, Donald J. Smythe discusses impossibility and 
impracticability. Should parties be excused from their contractual obligations when performance costs have increased substantially? The early literature analyzed this issue in terms of risk allocation. Smythe shows how more recent literature extends these original insights, for instance by framing the problem in terms of an optimal damages problem, which integrates the results with the literature on optimal contract remedies.

Peter van Wijck surveys the literature on foreseeability in Chapter 12. The Hadley Rule limits damages for breach of contract to the level of foreseeable losses. The main economic function of this default rule is to induce parties to reveal information on the high potential magnitude of the harm. Van Wijck argues that the Hadley Rule should not be seen as a penalty default rule that is deliberately set at a level the parties do not want. While efficiency gains of the Rule are somewhat limited because default rules tend to be sticky, there are some empirical indications that suggest that the Hadley Rule is the superior default rule when compared to the full damages rule.

Recently, economists have started to apply option theory to contract remedies. The idea is that a contract that is enforced through damages can be seen as an option contract, because it gives the promisor an option to either perform or pay damages. Abraham L. Wickelgren surveys this literature in Chapter 13, and discusses in particular how option contracts affect ex post holdups.

In the final chapter of Part II, Chapter 14, Klaus Wehrt reviews the literature on warranties. He shows that market practices tend to make sense only when models include bilateral incentive problems and behavioral aspects.

Part III of this volumes deals with long-term contracts. There is an extensive theoretical economic literature on long-term and relational contracts, written by institutional economists working in the field of industrial organization. Nick van der Beek surveys this economic literature in Chapter 15. The subsequent implications for law and contract drafting are discussed in Chapter 16, written by Mireia Artigot i Golobardes and Fernando Gómez Pomar. Finally, Antony W. Dnes reviews the literature on two specific long-term contracts: marriage contracts, in Chapter 17, and franchise contracts, in Chapter 18.

The final part of this volume, Part IV, consists of three chapters that offer varied perspectives. In Chapter 19 Ann-Sophie Vandenberghe reviews behavioral law and economics and its applications in the field of contract law. She shows that the behavioral approach is very promising for consumer contracts, but still of limited value when it comes to explaining general contract law. Ejan Mackaay, in Chapter 20, discusses the economic literature on the typical features of contract law in civil 
law countries. Law and economics is a scholarly product developed in common law systems, but Mackaay explains why it is equally applicable to civil law systems. Mackaay pays special attention to some typical features of civil law systems, such as codification, good faith, defects of consent, cause, penalty clauses, force majeure, and specific performance. In the last chapter, Chapter 21, Christopher T. Wonnell reviews the economic literature on unjust enrichment and quasi-contracts, a distinct though closely related field.

\section{References}

Barton, J.H. (1972), 'The Economic Basis of Damages for Breach of Contract', Journal of Legal Studies, 1, 277-304.

Birmingham, R.L. (1969), 'Damage Measures and Economic Rationality: The Geometry of Contract Law', Duke Law Journal, 49-71.

Bolton, Patrick and Dewatripont, Mathias (2005), Contract Theory, Cambridge, MA: MIT Press.

Coase, Ronald H. (1960), 'The Problem of Social Cost', Journal of Law and Economics, 2 , $1-44$.

Posner, Richard A. (1973), Economic Analysis of Law, Boston, MA: Little Brown.

Tullock, Gordon (1971), The Logic of the Law, New York: Basic Books. 